\title{
1. Introduction: democratic, institutional and legal implications of the commons for global governance
}

\author{
Samuel Cogolati and Jan Wouters*
}

\begin{abstract}
The most important lesson for public policy analysis derived from [my] intellectual journey ... is that humans have a more complex motivational structure and more capability to solve social dilemmas than posited in earlier rational-choice theory. Designing institutions to force (or nudge) entirely self-interested individuals to achieve better outcomes has been the major goal posited by policy analysts for governments to accomplish for much of the past half century. Extensive empirical research leads me to argue that instead, a core goal of public policy should be to facilitate the development of institutions that bring out the best in humans.
\end{abstract}

(Ostrom, 2009b: pp. 435-6)

\section{BACKGROUND}

Since the award of the Nobel Prize in Economic Science in 2009, the pioneering work of Elinor Ostrom on the commons has been given worldwide exposure. Her acceptance speech on that occasion, entitled 'Beyond Markets and States: Polycentric Governance of Complex Economic Systems' (2009), summarized neatly her lifelong effort to unearth the regulating principles and the institutional architecture that accounted for the success of innovative modes of decentralized and bottom-up governance, beyond the much travelled paths of the exclusively public or exclusively private management solutions. Her research, based on extensive fieldworks and relying on three decades spent refining her 'Institutional Analysis and Development' (IAD) framework, looks into the previously underestimated achievements of regimes of self-organization at all levels of governance (Drago Aligica and Boettke, 2009). Her central claim turned conventional wisdom upside down: complex socio-ecological systems (in which goods are subtractable and beneficiaries are hard to exclude) can prove to be sustainable resource domains granted that its stakeholders adopt a polycentric and self-regulated mode of governance. Ostrom's work serves as the background to this book. 
Our main endeavour throughout this volume, that builds in part upon an earlier book published in this series (Wouters et al., 2015), will be to assess to what extent this polycentric and self-regulated mode of governance is amenable to new democratic, institutional and legal arrangements at the global level. This book therefore shifts from the traditional focus of the academic literature on small-scale commons and local institutional arrangements. Indeed, the commons used to be, in medieval times, pastures and woodlands that, by custom, could be accessed and jointly managed by a community of villagers. Before Ostrom, the commons were brought back to the attention of the scientific community by the popular article of the American scientist Garrett Hardin: 'The Tragedy of the Commons' (1968). Hardin described an economic model devoid of any empirical evidence but based on rational-choice theory, in which individual actors automatically tend to over-exploit and plunder common-pool resources (CPRs) that are freely available to everyone. Prior to Ostrom's work, it was widely admitted that the twin features of CPRs, namely their difficulty to exclude and the rivalrous nature of the goods they either contained or produced, would lead to a collective action problem akin to the prisoner's dilemma (Olson, 1965). Hardin's prediction of no cooperation is entirely consistent with this inexorable dilemma. Hardin illustrates this with the example of an open-access pasture on which self-interested herders use as much grass as possible to rear their cattle. The commoners, assumed to be rational, incommunicative and selfish agents, are locked into short-term strategies and keep subtracting as much as possible from what Hardin mistakenly termed the 'commons'. The inevitable result is their degradation and depletion. According to Hardin, '[f]reedom in a commons brings ruin to all' (p. 1244). To avoid the unconstrained over-exploitation of natural resources by selfish individuals, Hardin only believes in two possible coercive arrangements: the enclosure of resources through private property, or, failing that, public regulation (p. 1247). Even though he admits that the legal institution of private property is 'unjust', he claims that there is no 'better system': '[t]he alternative of the commons is too horrifying to contemplate' (p. 1247).

As we know, despite the influence up until today of Garrett Hardin's narrative (see Ranganathan, 2016), the story did not stop here. In her landmark book Governing the Commons (1990), Elinor Ostrom showed through various case studies how local communities could develop autonomous institutions with their own ad hoc rules to govern the resource domains upon which they depend for their subsistence. In her book that quickly became the standard reference in the study of the commons, Ostrom examines the factors that lead self-governance mechanisms to succeed Swiss Alpine pastures, irrigation systems in Spain, Turkish or Sri Lankan 
fisheries. Commons have indeed existed over long periods of time and one of the reasons for their long-enduring success is that commoners do not always act as homines economici. Commoners are social actors embedded in tight-knit communities that communicate, observe social norms and judge their fellow members on the basis of their reputation. Consequently, commoners are capable of collectively making some binding decisions that supply institutions, refrain their individual consumption and preserve their resource domains in the long run. Despite the wide diversity of local arrangements, Ostrom identifies eight 'design principles' for commonsbased institutions that characterize sustainable institutions for collective action in the long term, among which are clearly defined jurisdictional boundaries, clear rules of access and use, conflict-resolution mechanisms that foster mutual trust, and sanctions to deter free-riders (p. 90). In brief, in exploring the empirical realities behind the management of CPRs, Ostrom rebutted Hardin's assumption that commons equate open-access regimes. She proved that it was possible to prevent commons from collapsing through institutions that are neither 'all-private', nor 'all-public', but collectively owned. She convincingly showed that the pessimistic outcome of the prisoner dilemma was misleading.

Since Governing the Commons (1990), many researchers have adopted Ostrom's IAD framework to scrutinize the governance of CPRs, be they local and natural, or more ground-breaking such as knowledge or cultural commons. There have been innumerable case studies assessing the robustness of the governance models suggested by Ostrom and refining her findings. Ostrom's design principles have been applied in very different contexts, beyond the sole issue of natural resource management. Her work opened the eyes of many academics to the fact that CPRs were not doomed to a tragic fate unless they were either enclosed and commercialized or turned into public property and administered by the state. Seen in this light, the commons have been burdened by some authors with the responsibility of carving out an autonomous social space independent from both the atomism of capitalist markets and the hierarchical structure of the state. Not only this, but the commons have been embraced by civil society and social activists as a new governance model to rethink the traditional public-private and market-state divides, and to prioritize ecological and human needs of communities (Bollier and Helfrich, 2012; 2015). It is Ostrom's seminal work and the ensuing academic and political debates around the commons, which laid the groundwork for this interdisciplinary book on a new system of global governance. 


\section{DEFINITIONS}

Far from being a monolithic notion, the commons today evoke a wealth of - sometimes contradictory - meanings. This is not different in the various chapters of this book. Whereas some authors focus on welldefined resource domains at the local or global levels, others insist that the commons are primarily about social and political movements against the top-down logic of markets and states. By way of introduction, we attempt to outline below some basic definitions for the notions of the commons (2.1), the common (2.2), global commons (2.3), and global public goods (GPGs) (2.4).

\subsection{Commons}

To explain the notion of the 'commons', it is usual to resort to the basic economic classification of goods. Contrary to public goods, which are non-rival, CPRs are rival in consumption, and therefore vulnerable for depletion. Yet, today, the commons no longer exclusively refer to tangible CPRs like pastures, seeds, forests or water reserves, but also to intangibles resources such as the Internet, software codes and human genes. Under Ostrom's influence, the commons have become more closely connected with the collective self-governance and participatory mechanisms they imply, than with the strict category of (rivalrous and non-excludable) economic goods they used to refer to. The commons can no longer be abstracted from the social networks which participate in their production and protection: without communities, no commons. This is why we do not simply speak of common 'goods' in this book. Even though it is impossible to apply one single and closed definition, we describe the commons as a social system consisting of three cumulative elements:

1. A common-pool resource, be it a tangible, natural resource like pastures, lands, seeds, forests or water reserves, or intangible resources such as traditional knowledge or the Internet (the object);

2. A community that has exclusive access to the resource in question and that manages it in common (the subject);

3. The practice of commoning: that is the concrete activity of governing a resource through collective action and according to ad hoc rules (the practice).

The rules constitutive of the practice of commoning will always be specific to each commons. So it is in this broad and plural sense, as an 'institution for collective action' (De Moor, 2011: p. 424), that the commons are most 
often understood in this volume. In this sense, the commons represent grassroots institutions developed by communities to share and govern tangible or intangible resources in a horizontal and autonomous fashion. It is this institutional and social element for self-government which makes the commons so different from privately or publicly owned resources.

\subsection{The Common}

Over the last decade, the commons have also acquired a strong political dimension. Ostrom's work has indeed sparked a new wave of interest for the commons as a 'third way' to overcome the extractive forces of capitalism and the top-down logic of states. In this sense, the commons have evolved into an alternative 'paradigm' to rethink the traditional private-public divide, and prioritize the ecological and human needs of communities over market and state. More and more authors nowadays identify the commons with political strategies of resistance like the commons movement in Italy (the Rodotà Commission that introduced into the Italian Civil Code a third category of beni communi beyond the public/private goods, the 2011 Water Constitutional Referendum), the indignados in Spain, the water war in Cochabamba (Bolivia), or the Occupy movement in the United States to overcome the extractive force of capitalism and the top-down logic of states (see also De Angelis, 2017: p. 10). They stress that the commons do not exist in a political vacuum of power relations; these are 'social systems' sustained in a competitive struggle against capitalist and state domination. In sum, the commons now serve as a new platform, language, social imaginary that speak to very diverse struggles of self-government against politics of enclosure.

In his landmark book Commun: Essai sur la révolution au XXIe siècle, co-written with Christian Laval, Pierre Dardot (who contributes Chapter 2 to this volume) defines the 'Common' as a political principle (Dardot and Laval, 2014). This principle is in line with what Michael Hardt and Antonio Negri wrote earlier in their book 'Commonwealth': ' $[\mathrm{t}] \mathrm{his}$ notion of the common does not position humanity separate from nature, as either its exploiter or its custodian, but focuses rather on the practices of interaction, care, and cohabitation in a common world, promoting the beneficial and limiting the detrimental forms of the common' (Hardt and Negri, 2009: p. viii). This normative approach to the common is shared by other contributors in the first part of this volume. For them, the common is not a thing limited to marginal areas of natural resource management, but rather a much broader set of practices which represent more direct forms of democracy and resistance against privatization. What these authors regret in Ostrom's work is that it does not sufficiently call into question 
the capitalist mode of production. In Chapter 5 of this volume, Pierre Sauvêtre even goes as far as to suggest that Ostrom's commons have 'no connection whatsoever with the movements for the common that appear in the 2000s in the context of the wave of state neoliberalization' (p. 80). The denomination of the common in the singular - in parallel with that of the commons - is warranted in this volume.

\subsection{Global Commons}

If we consider CPRs to be open access and rivalrous goods, we have to acknowledge that several of the resource domains on which we depend are to be found on a global scale. The atmosphere, the high seas, Antarctica, Outer Space, are all vast resource domains whose over-exploitation or misuse could potentially have disastrous consequences for every single individual regardless of his geographical location. Thus, the term 'global commons' has also been used to include these open resources. The United Nations Environment Programme (UNEP) has defined the global commons as 'resource domains or areas that lie outside of the political reach of any one nation State' (2017). More recently, the term has come to include common or global concerns of mankind such as biodiversity conservation and climate change (Ranganathan, 2016: p. 27). Some chapters in this volume also raise democratic, institutional and legal issues regarding such global commons.

However, for global commons, the leap from the local to the global level implies a qualitative change due to the structural absence of a community and of a widely recognized and implemented set of social norms regarding global resource domains. There is a lot of literature on the precise mechanisms that helped commoners to function and to overcome local constraints (Ostrom, 2005; 2009a). One reason why small-scale commons have proven to be sustainable is because they relied on a community whose tight-knit relationships often allowed them to design self-governance schemes and curb egoistic behaviour, notably due to the reiterated nature of the social interactions and the actors' concern for their reputation. In contrast, global commons are not managed by bottom-up institutions tailored by communities. As Tine De Moor already showed, global commons 'lack two important attributes that are characteristic of the commons as they have existed for centuries in Europe and beyond': 'institutionalization and self-governance' (2011: p. 422). This shows that scale matters in these issues (Ostrom et al., 1999; Berkes, 2006). Most global commons lack effective rules of control, management and access to regulate their use. In this sense, global commons seem to come more closely to the notion of common goods ('res communes') or open-access resources depicted 
by Garrett Hardin (1968). A distinction should be made between open access, on the one hand, and self-government by a limited number of users actively involved in the management of the commons, on the other. Global commons and commons should therefore not be confused.

In other words, areas labelled as global commons have little to do with Ostrom's commons and are, in fact, in dire need of a governance framework. Yet, even global collective action issues could possibly be overcome through reiterated interactions, the establishment of mutual trust and an institutional set-up entailing light monitoring and sanctioning mechanisms. The self-organization that is quintessential to the commons model of governance could potentially be found in larger networks of actors, challenging the previously held assumptions that autonomous self-governance should be reserved to small and thick communities. Admittedly, the efforts to coordinate action on the international scene to preserve or develop global commons have had some limited successes (for instance with regard to the mitigation of climate change: see Nordhaus, 1994). They nonetheless generated an exponentially growing literature on how to improve the design of their principles of governance (Stern, 2011). One important question in this volume is therefore whether it is possible to extrapolate the self-governance model of the commons to monitor the sustainability of wider shared resources at the global level.

\subsection{Global Public Goods}

Finally, some contributors to this volume use the concept of GPGs like climate change mitigation, the eradication of infectious diseases, the fight against corruption, or the protection of the ozone layer. One chapter even defines the rule of international law as a GPG of its own (see Groff and Karlsson-Vinkhuyzen, Chapter 7 in this volume). The notion of GPG is grounded in economic theory. As opposed to a private good, such as a pie or a car, a public good refers to something that is non-rival and non-excludable. Public goods represent a case of market failures - that is, goods and services that cannot be left to the invisible hand of the free market. By virtue of the inherent free-rider problem in the provision of public goods, coercive authority is considered necessary in ensuring, at the very least, a minimal contribution by all. Therefore, at the national level, state intervention is seen as indispensable in the financing and provision of public goods (Samuelson, 1954). In a popular book published by the UNDP Office of Development Studies in 1999, GPGs are defined as 'outcomes (or intermediate products) that tend towards universality in the sense that they benefit all countries, population groups, and generations' (Kaul et al., 1999: p. 16). 
This definition means that, in contrast to economic theory, the concept of 'goods', as reconstructed by Kaul et al., covers a very large spectrum of global issues. Under this approach, it should be stressed that there cannot be any fixed list of GPGs and the term 'good' should be understood in the broadest possible sense - not solely as a tangible commodity. GPGs simply point to policy challenges that cannot be adequately resolved at the state level and which, therefore, require collective action at the global level (Cogolati et al., 2016: p. 9). GPGs have gradually become a buzzword in the global policy discourse, evolving from a technical, economic concept to a powerful advocacy tool in favour of increased international cooperation and regulation in today's globalized world (p. 11). In fact, most goods cannot be inherently public: they normally become public through public provision. The choice for (or against) public provision is never a neutral one, as it is generally subject to diverging views. Even goods that are 'de facto public', on account of their non-excludability and non-rivalry, such as the lighthouse, may, under certain circumstances, be considered unworthy of public provision. For instance, a society could very well decide that, since the lighthouse only benefits foreign ships, it will not bear the cost thereof (p. 14). The authors of the UNDP book acknowledge this basic fact as well: "[p]ublic" and "private" are in many - perhaps most - cases a matter of policy choice: a social construct' (Kaul and Mendoza, 2003: p. 104).

The authors in this volume agree to draw a strict distinction between the commons and GPGs as models of governance. Pierre Dardot, for example, claims that the common implies a system of bottom-up governance, in contrast to GPGs theory, which is designed to promote more cooperation among existing private and state actors (see Chapter 2 in this volume). Indeed, the power of the commons discourse is to propose an alternative vocabulary and governance paradigm to that of the traditional market-state dichotomy. There are plenty of institutional arrangements which are formed by the communities themselves and which often prove more effective than the typical 'all-public' and 'all-private' solutions in safeguarding shared resources. In contrast, the urgency to produce GPGs seems to justify a turn to old public or private institutions which do not afford to communities the same right to participate and shape their own process of development (see also the Conclusion in this volume). Thus, instead of assimilating commons to GPGs, both governance frameworks should be cautiously distinguished to avoid the powerful alternative force of community-driven initiatives dressing up classic governance models (Cogolati, 2016: p. 18). 


\section{THE OBJECT AND PURPOSE OF THE BOOK}

The main purpose of this book is to understand what the ground-breaking model of cooperation of the commons implies for global governance, especially in relation to the debate on the (non)-democratic nature, institutions and legal underpinnings of global governance. The research on the implications of the commons for our system of global governance is still scarce. As Michel Bauwens writes in his foreword to this volume, " $[\mathrm{t}] \mathrm{he}$ time has come for researchers and scientists to focus their efforts on potential global governance mechanisms for the commons, existing or to come'. The present book therefore aims to contribute to fill the gap between the study of bottom-up commons and global governance. Global governance, which stands for ways of problem-solving cooperation that take place within global networks of relevant stakeholders, is indeed gradually substituting itself to the democratic deliberation within nation-states and comes to have more of a say over what political projects ought to be prioritized. In an interdependent and globalized world, a fair and representative system of global governance will therefore be critical to protect and promote the commons. Hence, we submit that the commons cannot only be studied at the micro-level, where they often emerge. While it is true that decisionmaking processes for the commons are generally locally owned, the commons also represent at a more macro-level a 'foundational paradigm of a generative revolution aiming at the construction of a new common sense' (Bailey et al., 2013: p. 19, referring to Bollier and Helfrich, 2012). Following this broader normative interpretation, the commons may also indicate a third way beyond both market and state on a global scale. Given the newly found importance of the commons in the political discourse, it has become necessary to explore the democratic, institutional and legal implications of the commons for global governance today.

In light of this, our principal research questions are:

1. Which democratic qualities and shortcomings in global decisionmaking processes do the commons reveal? Could global governance be democratized through participatory, decentralized and self-organized communities of 'commoners', and if so, in what form? Could the commons become vehicles for democratization at the global level? If so, what kind of democratic processes should ensure that shared resources be stewarded by communities at the global level?

2. What difference does it make in institutional terms to govern a resource domain as a commons? What kind of institutional cooperation schemes does the concept of the commons imply at the global level? Is it possible to extrapolate the governance of the commons at 
the global level for wider shared resources (such as biodiversity or scientific knowledge)?

3. How can the commons be operationalized as a matter of international law? What kind of legal norms and procedures should be devised at the global level to ensure that the commons be protected from enclosure and commodification?

In order to answer these research questions, this book takes a multidisciplinary view across a narrow range of disciplines: political theory, political science, political economy and international law. The commons have indeed been studied through analytical frameworks that can be (and have been) applied to a variety of case studies emanating from multiple scientific disciplines. Respectful of this diversity in the approaches but also in the objects of enquiry, we invited scholars from these four different disciplinary affiliations to contribute to the present volume, thereby assuming that the analytical frameworks associated with the governance of the commons can act as a conceptual bridge between the disciplines and allow for a mutually enriching dialogue across disciplinary boundaries. The themes of the different chapters as well as their authors have been carefully chosen bearing in mind this goal: we bring together scholars to develop a new research agenda surrounding the study of the commons and global governance. We attempt to present a sample of promising researches that lay a special emphasis on the democratic, institutional and legal implications of commons for global governance. Based first on the study of the commons as vehicles for democratization of global governance, then on the assessment of the role played by commons-based institutions in the current global governance system, and finally on a more normative interrogation around how international law ought to look to recognize and support the commons, this book will provide its reader with solid foundations to look further into the introduction of 'commoning' practices into global governance. However, the volume will not provide an exhaustive study of all the types and schemes of governance applied to commons; nor does it claim to present a silver bullet to democratize the current model of global governance. Its more humble objective is to illustrate through a handful of carefully chosen examples that the articulation of the commons in global governance constitutes a vast and rich field of research that calls for further study. 


\section{STRUCTURE}

The contributions in this volume can be divided into three parts: those chapters that wrestle with the democratic credentials of the politics of the commons and try to outline how the democracy of the global commons could look (democratic perspectives: 4.1); others that tackle institutional questions related to the provision of GPGs and management of global commons in more specific contexts (institutional perspectives: 4.2); and, finally, chapters on the possible contribution of international law to the protection of the commons (legal perspectives: 4.3).

\subsection{Democratic Perspectives}

First of all, four chapters look at global governance from the lens of the democratic practices linked to the commons. The democratic dimension was not entirely absent from Ostrom's work. It was rather implicitly present under concepts such as self-governance and participation. However, it was rarely thematized as such and most research conducted on the topic usually lacks a comprehensive account of the ways in which the governance of the commons could integrate some features of democracy. There is certainly no shortage of disagreement on the definition of democracy. Democracy has become the prime example of an 'essentially contested concept' (Gallie, 1956), that is a concept whose importance is denied by none but whose meaning is fiercely debated and regarding which neither eclecticism ('all answers are equally valid') nor dogmatism ('my answer is the exclusive truth') provide an appropriate approach (Garver, 1978: p. 168). It would be impossible to recap, even in broad brushstrokes, the intellectual debate that has surrounded democracy ever since its inception. For the purpose of the present book, we cut this Gordian knot by providing a first and minimal definition of democracy, upon which each contributor has been invited to elaborate further in Part I of the book. Democracy is referred to in this book as the institutional practice through which stakeholders deliberate and/or decide on the regulations that they are submitted to. Regarding the commons more specifically, a group of researchers - led by prominent public intellectuals such as Michael Hardt and Antonio Negri (2009), David Harvey (2011), Naomi Klein (2001) or Ugo Mattei (2011) - has suggested that - since the commons bring the empirical demonstration that self-governance, far from being a utopian ideal, is and long has been a lived reality - the latter could and should be turned into the conceptual matrix of a new account of democracy. The first aim of this volume is to indicate how this new account of democracy based on the commons could also be realized at the global level. 
This first part is mostly organized as a dialogue revolving around a chapter submitted by a prominent philosopher in the field, namely Pierre Dardot. In his chapter entitled 'What democracy for the global commons?' (Chapter 2), Dardot suggests that the governance of the commons could be turned into a more general political principle he calls 'the common' in the singular. The common would, in his view, imply to give the kind of collective cooperation quintessential to the governance of the commons a global scope and to export its cooperative strategies to all spheres of social activities. In order to institute the world as a common, he develops the new paradigm of 'cosmodemocracy'. According to Pierre Dardot, this new kind of global democracy based on the common will not come from above, but will emerge from a multiplication of bottom-up and decentralized institutions. The two subsequent chapters discuss critically this claim from two distinct angles. On the one hand, Dardot's suggested institutionalization of the common as an innovative form of multi-layered federalism is challenged by Nicolás Brando and Helder De Schutter. In 'Federal commons' (Chapter 3), they claim that since Dardot refuses to grant any prerogative to a central authority, his ideal model would be best described as 'confederal' or 'treaty-based' and would have to cope with the instability associated with this model of political association. On the other hand, Christiaan Boonen's response, 'A (non-)violent revolution? Strategies of civility for the politics of the common' (Chapter 4), argues that Dardot misjudges the role played by coercion and violence in the governance of the commons and consequently presents a too rosy picture of the type of governance that ought to be widespread into adjacent social spheres. Finally, in 'Forget Ostrom: from the development commons to the common as social sovereignty' (Chapter 5), Pierre Sauvêtre emphasizes the distinction between Ostrom's commons and the common. In a bold and challenging piece, he argues that the movement for the common that appeared in Catalonia (politica del comú) or in Bolivia (lo común) have in fact nothing to do with Ostrom's developmentalist approach.

\subsection{Institutional Perspectives}

Second, four other contributions look into the commons-based institutions which shape new collective rules, practices, and spaces in the current global governance system. As Tine De Moor writes in her Afterword, ' $[t]$ he topic of global resource governance, central to this book, is probably the most difficult angle to bridge several sides of the debate, but at the same time also the most obvious one: what binds those interested in commons together is a fundamental belief in the capacities in self-governance and collective action by citizens with the purpose of solving current major 
societal problems'. The objective of this second part is to evaluate to what extent institutional arrangements to govern the commons at the local level can also be applied at the global level for wider resources. Indeed, under Elinor Ostrom's impulse, the commons have been studied as new 'community institutional arrangements' that can operate at multiple scales, including at the global level (Ostrom, 2009a). This is what distinguishes commons from CPRs that are left without any clear access rules and governance mechanisms. As indicated above, much of the literature used the IAD framework developed by Vincent and Elinor Ostrom as a new methodology for investigating commons-based institutions across different contexts and according to bounded variables. This is particularly clear in their polycentric (as opposed to 'monocentric') approach involving the combination of various self-organized centres of decision-making - at the local, regional, national and global levels - that are formally independent of each other but enter into cooperative undertakings (Ostrom et al., 1961; Bauwens and Mertens, 2018). Yet, what is still less known is whether such bottom-up institutional and polycentric arrangements can be extrapolated at the global level for wider and transnational resources like, for example, biodiversity or the academic publishing industry. Under the current political system, strongly relying on both markets and states as basic units, the commons too often operate under the radar of global governance researchers. This book therefore proposes to build on the lessons learned from commons scholarship in order to explore ways for making institutions of global governance more participatory and accountable to communities across the world.

This second part is organized as follows. In 'Governance of the global commons: a question of supply and demand, the answer of polycentricism' (Chapter 6), Rutger Hagen and Christophe Crombez draw lessons from the study of the local commons and apply them to the governance of global commons. They use the economic adage of demand and supply to better understand what kind of collective action problems exist in global governance and how they may be solved. They realize that in smaller settings with fewer participants and increased trust among each other, institutional formation is relatively easy. However, when local commons-based arrangements are transposed to the global level, monitoring and sanction mechanisms become less effective, and uncertainty is higher. Thus, in their view, it is not sufficient to replicate local arrangements at the global level; local initiatives must be linked to regional and global regimes in a multi-layered and polycentric system of governance. In 'The rule of law and accountability: exploring trajectories for democratizing governance of global public goods and global commons' (Chapter 7), Maja Groff and Sylvia KarlssonVinkhuyzen advance that international legal cooperation geared towards 
granting a global scope to the rule of law is instrumental in facilitating the protection of global commons and turning its governance into a democratic endeavour. They describe the international rule of law as a foundational GPG of its own. In addition to institutional change, the authors also plead for 'attitudinal change' in order to strengthen accountability and democracy in global governance. In 'Expropriation by definition? Regime complexes, structural power, and global public goods' (Chapter 8), Thomas R. Eimer looks into the mechanisms that (fail to?) ensure the protection of a specific global commons - in this case, biodiversity - in spite of the huge imbalances in the distribution of power among the various stakeholders. Maarja Beerkens's chapter, 'Knowledge commons and global governance of academic publishing' (Chapter 9), digs deeper into the barriers to a free flow of scientific knowledge raised by the oligopolistic academic publishing industry. Beerkens underscores the different types of efforts that have been undertaken to turn this scientific knowledge into a knowledge commons, and she shows how this shift requires new institutions inspired by selforganization mechanisms beyond market and state hierarchies.

\subsection{Legal Perspectives}

Third and last, four chapters will question from a normative point of view whether international law as it stands is conducive to the protection of the commons against enclosure and commodification. It is true that the question of legal norms, institutions, and procedures is far from new in the debate on the governance of the commons. In particular, the literature has called for a shift from a traditional system of law based on the protection of individual private property rights, to a new legal order that promotes stewardship of resources by communities. Legal scholars have been invited to rethink the links between communities, shared resources and property rights at the domestic level. Hence, most scholars have focused on shared property regimes (Fennell, 2011; Orsi, 2013), intellectual property regimes to protect knowledge commons (think of the 'Creative Commons License' that protects shared resources) (Frischmann et al., 2014), and public trust doctrines (think of rivers, shorelines and parks protected by the state for future generation) (Wood, 2013). However, what has been overlooked for too long is the role that international law can play in the protection of the commons as institutions of their own. It is true that international legal scholarship has long recognized areas and resources beyond state jurisdiction (like the high seas, the deep seabed, outer space, the Moon and other celestial bodies, as well as Antarctica) as 'global commons'. However, it has given much less attention to commons defined in Ostrom's sense as bottom-up self-governance institutions. Whereas transnational areas 
and natural resources are now subject to special treaty regimes between states (like the common heritage of mankind), it remains unclear to what extent international law can protect communities from dispossession of their commons. This volume therefore takes a new look at the potential instrumental role of international law in safeguarding the autonomous and collective institutions established by the communities themselves to manage resources in common.

Ugo Mattei, the Senior Scholar winner of the 2017 international Elinor Ostrom Award on Collective Governance of the Commons, accepted to respond to this challenging question based on his latest book The Ecology of Law: Towards a Legal System in Tune with Nature and Community (co-written with F. Capra, 2015). In 'The ecology of international law: towards an international legal system in tune with nature and community?' (Chapter 10), Mattei calls for a paradigm shift (an 'ecolegal revolution') in international legal jurisprudence from the materialistic and extractive mentality of the Industrial Age to a new vision of the world as a network based on generative ecological principles. Based on a radical ecological reading of international law, he comes to the conclusion that international law is in itself flawed and incapable of protecting small-scale commons. In 'From eroding to enabling the commons: the dual movement in international law' (Chapter 11), Olivier De Schutter proposes a somewhat more optimistic view of international law. While De Schutter concedes in line with Mattei that international law was at its origins a project aimed at the enclosure of the commons, he shows that a counter-movement is currently emerging from the human rights community to resist the commodification of natural resources. In our own substantive contribution to this volume, 'International law to save the commons' (Chapter 12), we build on the same premise that international law can serve as a potential and additional strategic tool for local communities to reclaim the commons. We show that international and regional human rights instruments can be interpreted in a progressive way so as to protect the commons upon which millions of small-scale farmers, pastoralists, forest-dwellers, artisanal fishers and indigenous peoples depend for their survival around the world and in the Global South specifically. Like Olivier De Schutter, we also point to the project of a UN Declaration of the Rights of Peasants, which provides in its latest draft version a stand-alone obligation 'to recognise and protect the natural commons and their related systems of collective use and management' (United Nations General Assembly, 2017: Article 17(3)). This recent development suggests in our view, for the first time, the existence of a window of opportunity for a new international human right to the commons. Last but not least, in 'Procedure and substance in international environmental law and the protection of the global commons' (Chapter 13), Jutta Brunnée 
explores the procedural aspects of international environmental law's evolution towards promoting global governance of the global commons. Some global environmental concerns are so complex that she shows that strong procedural obligations can sometimes better serve community interests in the protection of the global commons.

Finally, Martin Deleixhe concludes this volume with this bold question: 'is the governance of the commons a model for a new global governance?' After recalling the proto-democratic, decentralized and bottom-up character of the commons, he argues that the commons indeed put forward an innovative political model to reform global governance. Whereas GPGs require in his view a strong and centralized authority, commons offer a more legitimate polycentric form of federalism which has the potential to democratize global governance.

To sum up, the added value of this volume is that it breaks down the barriers between the studies of commons and wider systems of global governance, and that it connects research agendas that share more theoretical insights than has been traditionally assumed. It elevates the academic debates on the commons by indicating in what ways these bottom-up institutions can also transform the current system of global governance.

\section{NOTE}

* The co-editors would like to thank Dr Martin Deleixhe, who contributed to an earlier draft of this introduction and Professor Dr Tine De Moor, who provided very useful comments.

\section{REFERENCES}

Bailey, S., Farrell, G. and Mattei, U. (eds) (2013) Protecting Future Generations through Commons. Strasbourg, Council of Europe Publishing.

Bauwens, T. and Mertens, S. (2018) Social Economy and Polycentric Governance of Transitions. In: Cassiers, I., Maréchal, K. and Méda, D. (eds) Post-growth Economics and Society: Exploring the Paths of a Social and Ecological Transition. Oxon and New York, Routledge, pp. 45-62.

Berkes, F. (2006) From Community-based Resource Management to Complex Systems: The Scale Issue and Marine Commons. Ecology and Society, 11 (1), 45.

Bollier, D. and Helfrich, S. (eds) (2012) The Wealth of the Commons: A World Beyond Market and State. Amherst, Levellers Press.

Bollier, D. and Helfrich, S. (eds) (2015) Patterns of Commoning. Amherst, Levellers Press.

Capra, F. and Mattei, U. (2015) Toward a Legal System in Tune with Nature and Community. Oakland, Berrett-Koehler Publishers. 
Cogolati, S. (2016) Global Public Goods or Commons as a Lens to Development? A Legal Perspective. Leuven Centre for Global Governance Studies Working Paper No. 179. November 2016. [Online] Available from: https://ghum.kuleu ven.be/ggs/publications/working_papers/2016/179cogolati (accessed 25 January 2018).

Cogolati, S., Hamid, L. and Vanstappen, N. (2016) Global Public Goods and Democracy in International Legal Scholarship. Cambridge Journal of International and Comparative Law, 5 (1), 4-30.

Dardot, P. and Laval, C. (2014) Commun: Essai sur la révolution au XXIe siècle. Paris, La Découverte.

De Angelis, M. (2017) Omnia Sunt Communia: On the Commons and the Transformation to Postcapitalism. London, Zed Books.

De Moor, T. (2011) From Common Pastures to Global Commons: A Historical Perspective on Interdisciplinary Approaches to Commons. Natures Sciences Sociétés, 19 (4), 422-31.

Dragos Aligica, P. and Boettke, P. (2009) Challenging Institutional Analysis and Development: The Bloomington School. London, Routledge.

Fennell, L. A. (2011) Ostrom's Law: Property Rights in the Commons. International Journal of the Commons, 5 (1), 9-27.

Frischmann, B. M., Madison, M. J. and Strandburg, K. J. (eds) (2014) Governing Knowledge Commons. New York, Oxford University Press.

Gallie, W. B. (1956) Essentially Contested Concepts. Proceedings of the Aristotelian Society, 56, 167-98.

Garver, E. (1978) Rhetoric and Essentially Contested Arguments. Philosophy and Rhetoric, 11 (3), 156-72.

Hardin, G. (1968) The Tragedy of the Commons. Science, 162 (3859), 1243-8.

Hardt, M. and Negri, A. (2009) Commonwealth. Cambridge, Harvard University Press.

Harvey, D. (2011) The Future of the Commons. Radical History Review, 109, 101-7.

Kaul, I. and Mendoza, R. U. (2003) Advancing the Concept of Public Goods. In: Kaul, I., Conceição, P., Le Goulven, K. and Mendoza, R. U. (eds) Providing Global Public Goods: Managing Globalization. New York, Oxford University Press, pp. 78-111.

Kaul, I., Grunberg, I. and Stern, M. (1999) Defining Global Public Goods. In: Kaul, I., Grunberg, I. and Stern, M. (eds) Global Public Goods: International Cooperation in the 21st Century. New York, Oxford University Press, pp. 2-19.

Klein, N. (2001) Reclaiming the Commons. New Left Review, 9, 81-9.

Mattei, U. (2011) Beni comuni: Un manifestó. Roma, Laterza.

Nordhaus, W. D. (1994) Managing the Global Commons: The Economics of Climate Change. Cambridge, MIT Press.

Olson, M. (1965) The Logic of Collective Action: Public Goods and the Theory of Groups. Cambridge, Harvard University Press.

Orsi, F. (2013) Elinor Ostrom et les faisceaux de droit: l'ouverture d'un nouvel espace pour penser la propriété commune. Revue de la régulation, 14, DOI: 10.4000/regulation.10471.

Ostrom, E. (1990) Governing the Commons: The Evolution of Institutions for Collective Action. Cambridge, Cambridge University Press.

Ostrom, E. (2005) Understanding Institutional Diversity. Princeton, Princeton University Press. 
Ostrom, E. (2009a) A General Framework for Analyzing Sustainability of Socialecological Systems. Science, 325 (5939), 419-22.

Ostrom, E. (2009b) Beyond Markets and States: Polycentric Governance of Complex Economic Systems. Nobel Prize Lecture. 8 December 2009. [Online] Available from: https://www.nobelprize.org/nobel_prizes/economic-sciences/ laureates/2009/ostrom_lecture.pdf (accessed 8 January 2018).

Ostrom, V., Tiebout, C. M. and Warren, R. (1961) The Organization of Government in Metropolitan Areas: A Theoretical Inquiry. American Political Science Review, 55 (4): 831-42.

Ostrom, E., Burger, J., Field, C. B., Norgaard, R. B. and Policansky, D. (1999) Revisiting the Commons: Local Lessons, Global Challenges. Science, 284 (5412), 278-82.

Ranganathan, S. (2016) Global Commons. European Journal of International Law, 27 (3), 693-717.

Samuelson, P. (1954) The Pure Theory of Public Expenditure. The Review of Economics and Statistics, 36 (4), 387-9.

Stern, P. C. (2011) Design Principles for Global Commons: Natural Resources and Emerging Technologies. International Journal of the Commons, 5 (2), 213-32.

United Nations Environment Programme. (2017) Global Commons. [Online] Available from: http://staging.unep.org/delc/GlobalCommons/tabid/54404/ Default.aspx (accessed 20 November 2017).

United Nations General Assembly (2017) Promotion and Protection of the Human Rights of Peasants and Other People Working in Rural Areas. Human Rights Council. Thirty-sixth session. 25 September 2017, UN Doc. A/HRC/36/L.29.

Wood, M. C. (2013) Nature's Trust: Environmental Law for a New Ecological Age. Cambridge, Cambridge University Press.

Wouters, J., Braeckman, A., Lievens, M. and Bécault, E. (eds) (2015) Global Governance and Democracy: A Multidisciplinary Analysis. Cheltenham, UK, and Northampton, MA, USA, Edward Elgar. 